\title{
Os itinerários do Fantástico em "0 Guarda-Chaves»
}

\section{Maria Nazareth Soares Fonseca}

A irrupção do insólito no conto "O Guarda-Chaves" de Juan José Arreola ${ }^{1}$ dá-se de forma singular. No nível do enunciado, percebe-se o jogo que se estabelece a partir da designação de "forasteiro" dada ao indivíduo que chega à estação para aguardar o trem que o levará a T. "Forasteiro", substituindo "viajante", remete à idéia de estranho, daquele que não é do lugar e que, por isso, nada sabe da região e de seus costumes. Estabelece-se, desse modo, uma diferença entre o forasteiro que "ignora completamente o que está acontecendo" (p. 37) e a figura do guarda-chaves, um velhinho "de vago ar ferroviário" (p. 37) que propõe questões e articula respostas que irão (des) realizar o universo de probabilidades e de sentido para o viajante.

"Nota-se que o senhor ignora completamente o que está acontecendo" é o que diz o guarda-chaves ao forasteiro, quando esse lhe fala da necessidade de chegar a $\mathrm{T}$ no dia seguinte. As formas "ignora" e "está acontecendo" denotam, para o leitor, um impedimento não duradouro, uma dificuldade passageira que pode ser superada. O desenrolar do conto, no entanto, vai atribuindo ao tempo presente um sentido de permanência, de continuidade, processo esse que intensifica, na situação, as marcas de uma temporalidade não limitada. O texto, então, atua seguindo uma estratégia que desarticula as previsões do leitor e faz instalar a estranheza e a insegurança.

Deve-se notar que o absurdo, no conto, não se realiza a partir de acontecimentos "reais" pelos quais passa determinada perso-

1. ARREOLA, Juan José. O Guarda-Chaves, In: Confabulário Total. Trad. Luiz Papi e Haroldo Bruno. Rio de Janeiro. Edinova, 1969. 
nagem. O mundo de incertezas e de anormalidades delineia-se a partir da fala do velho que ressalta as contradições do sistema ferroviário do país, "famoso por suas estradas de ferro" (p. 38), mas que não tem sequer o controle do funcionamento dos trens $\mathrm{e}$ nem condições de assegurar a existência de trilhos em todas as regiões do país. Em alguns povoados, afirma o guarda-chaves, "eles estão apenas marcados no caminho, por meio de riscas de giz" (p. 38)

A fala do guarda-chaves contrapõe-se à escrita dos boletins da empresa ferroviária que garantem o bom funcionamento dos trens. $\widehat{E}$ com sua fala que o guarda-chaves manipula as informações e mantém sob seu poder os incautos viajantes, porque esses, não tendo acesso às informações escritas pela companhia, não podem duvidar das estórias que lhes são contadas. A fala do guarda-chaves garante, assim, uma imagem que ele faz dos seus ouvintes e lhe possibilita conduzir o diálogo de modo que o destinatário apareça sempre como incapaz de reverter essa situação de dominação.

Da mesma forma que o guarda-chaves domina pela fala a ação do viajante, a voz do narrador é também sufocada por ele, que se transforma, assim, no decodificador todo poderoso do sistema ferroviário. Seu relato se constrói, ao longo do conto, num jogo em que, embora em situação de diálogo, o viajante, ainda que fale, é sempre o ouvinte passivo, dominado pela fala-poder do guarda-chaves.

Por outro lado, a interação entre a fala guarda-chaves e o sentido previsto pelo leitor faz-se através de ambiguidades e introduz a hesitação que, conforme afirma Irene Bessiêre, retomando o ponto de vista de Tzvetan Todorov, "deve ser a atitude ideal do leitor diante do fantástico". ${ }^{2}$

A fala do guarda-chaves tece-se, pois, da relativização do provável-improvável:

"Na verdade, a nação dispõe de numerosos trens $e$ os passageiros podem utilizá-los com relativa facilidade, mas sempre levando em conta que não se trata de um serviço comum e definitivo. Em outras palavras, ao tomar um trem, ninguém espera ser conduzido ao lugar que deseja”. (p. 3)

2. BESSIERE, Irène. Le récit fantastique. La poètique de l'incertain. Paris, Larousse, 1974. p. 164. 
A situação de ameaça que não pode ser afastada, pois a cada questão proposta pelo viajante corresponde uma explicação que recupera o absurdo, faz aflorar a ineficácia da ação do homem ante o inevitável. Tal situação recupera, num certo sentido, a perplexidade que se observa em alguns dos romances de Kafka ( $O$ processo ou $O$ castelo, por exemplo), nos quais o homem é colocado como presa de um contexto de esmagamento e aniquilação irremovível.

Tanto nos citados romances de Kafka quanto no conto de Arreola, a intromissão brutal do irracional na vida de todos os dias delineia a inutilidade de luta, já que o inadmissível e o irracional configuram um "état du fait logique" " que calca no ser humano a sua impotência. Como em Kafka, há em "O Guarda-Chaves" um poder superior que tudo (pre) vê, tudo determina, aprisionando o homem em suas malhas fantásticas.

Há, no entanto, no conto de Arreola, como que contraponteando com o mal que advém da imprevisibilidade e da insegurança dos trens e dos itinerários a serem percorridos, situações aparentemente positivas que resultam desse sistema caótico. A aldeia de $\mathbf{F}$ nasceu da impossibilidade de os passageiros chegarem ao destino desejado; a inexistência de uma ponte fez surgir entre os passageiros o esforço comunitário: "desarmaram o trem e o levaram, peça por peça, nos ombros para o outro lado do abismo (...)" (p. 40). Tais acontecimentos, todavia, traduzem mais significativamente a passividade dos homens ante o determinado. Não há luta por parte dos usuários que, sem reação e sem protestos, aceitam a opressão e o desmando da empresa ferroviária. Ainda como em Kafka, uma lei maior determina o que fazer e inibe qualquer tentativa de reação ao poder instituído e "de là naît la grande deroute", como acentua J-B Baronian.4

Nota-se ainda, no conto, que o apelo ao fantástico reforça as ações bizarras da empresa ferroviária. Incapaz de garantir a execução dos planos de construção dos itinerários e de assegurar a constância dos trens, a empresa inclui, para as viagens sem itine-

3. BARONIAN, J-B. Uu nouveau fantastique. Lausanne, L'age d'homme, 1977. p. 34 .

4. BARONIAN, J-B. idem, ibidem. 
rários e duração previstos, um vagão câmara-ardente e um vagãocemitério para onde vão os cadáveres dos passageiros que morrem nestas trajetórias sem fim. Para solucionar o problema da espera interminável nas estações, criam-se escolas "onde os futuros viajantes recebem lições de urbanidade e entretenimentos adequados". . (p. 41)

As contradições da empresa ferroviária - senhora absoluta do destino de seus passageiros - são enumerados pelo guarda-chaves com sensivel ironia o que dá à sua fala uma duplicidade de sentido que reforça a perplexidade do leitor. Percebe-se que as extravagantes estórias de viagens são contadas com o intuito de explicitar uma outra viagem que se articula no avesso de seu discurso. Sua fala é, ao mesmo tempo, enigma a ser decifrado e revelação de segredos ocultos. O guarda-chaves, funcionando como o recebedor das estórias pelos viajantes, fornece, ao (re)'contá-las, as chaves para a decifração de um outro sentido que perpassa a fantasticidade dos eventos narrados. Em meio ao emaranhado de acontecimentos, instaura-se um desvio de sentido ligado ao processo de relativização, suscitado por um jogo de ambivalência $:^{5}$ os trens são imprevisíveis, os itinerários não obedecem às necessidades dos viajantes, existem estações que "são pura aparência (...), são como decorações do teatro" (p. 41), mas, paradoxalmente, o trem que levará X a T chega à hora e à estação previstas.

Contrariamente aos relatos fantásticos tradicionais, o jogo esconder-revelar dá-se, no conto, de forma a garantir o privilégio da revelação de fatos e acontecimentos pelo guarda-chaves que, no entanto, jamais empreendera qualquer viagem naqueles trens ou por aqueles caminhos estranhos. O revelar é passado ao viajante, desse modo, de "segunda-mão", o guarda-chaves não assumindo a veracidade do narrado, prendendo, porém, a atenção do viajante (e do leitor) pela sedução de sua fala. O discurso do guarda-chaves articula-se, assim, num duplo sentido: uma mentira possível ou uma possível verdade. ${ }^{16}$ A ligação fluida entre um pólo e outro assegura a convergência de referências que constroem a fantasticidade do relato e $\mathrm{A}$ anormalidade da empresa ferroviária metaforiza

5. BESSIERE, Irène. obra citada. p. 74 .

6. Idem, ibidem. p. 87 . 
uma outra anormalidade, a de uma realidade concreta que garante a relação com o mundo do leitor, concretamente situado num contexto em que os eventos inusitados reescrevem situações possíveis, que verossimilizam a ficção.

O guarda-chaves, ao utilizar as estórias que ouviu (ou inventou ele mesmo?) como chaves que permitem o acesso ao desequilíbrio da ordem do mundo vivido, assume o fantástico como reforço ou explicitação desse desequilíbrio e faz emergir uma situação problematizadora. A perplexidade do seu relato reenvia, por fim, o leitor a uma nova forma de hesitação. O trem que levará $\mathrm{X}$ a $\mathrm{T}$, chegando à hora marcada, reativa a ambiguidade típica do fantástico, embora a estratégia de interpretações do texto não deixe de estar assegurada. ${ }^{7} \mathrm{E}$, paradoxalmente, como aceitua Sartre, a ruptura da ligação com o mundo real, instaura, ao mesmo tempo, uma comunhão com esse mesmo mundo. ${ }^{8}$

7. ECO, Umberto. Leitura do texto literário. Lector in fabula, Trad. Mário Brito. Lisboa, Editorial Presença, 1983. p. 63.

8. SARTRE, Jean Paul. Aminabad, ou du fantastique consideré comme un langage. Apud. EUROPE, revue mensuelle - 58: (611) Paris, Mar 1980, p. 29 . 